\title{
Upaya Badan Penanggulangan Bencana Daerah (BPBD) dalam penanggulangan bencana banjir
}

\author{
Ahmad Udori *, Miranti Miranti \\ Program Studi Ilmu Pemerintahan, Fakultas Ilmu Sosial dan Ilmu Politik, Universitas Muara Bungo \\ * Corresponding Author. E-Mail: ahmadudoriumb@gmail.com
}

\begin{tabular}{|c|c|}
\hline Info Artikel & Abstrak \\
\hline Histori Artikel: & Dari hasil penelitian penulis yang berjudul Kinerja Badan Penanggulangan Bencana \\
\hline Received: 9 Dec. 2019 & Daerah Dalam Penanggulangan Bencana Banjir Di Kabupaten Tebo (Studi Kasus \\
\hline Revision: 18 Dec. 2019 & BPBD Kab. Tebo) sebagai berikut: Upaya Pemerintah Badan Penanggulan Bencana \\
\hline Accepted: 31 Dec. 2019 & Daerah dalam menanggulangi Bencana Banjir. Sosialisasi Pesiapan menghadapi banjir \\
\hline $\begin{array}{l}\text { Kata Kunci: upaya } \\
\text { BPBD; penanggulangan } \\
\text { bencana; bebas banjir; } \\
\text { BPBD efforts; disaster } \\
\text { management; flood free }\end{array}$ & $\begin{array}{l}\text { Sosialisasi ini dilakukan untuk masyarakat Pemerintah Kabupaten Tebo supaya lebih } \\
\text { tahu bagaimana persiapan mengahadapi banjir di kelurahan tesebut. Supaya disaat } \\
\text { bencana banjir datang masyarakat tidak terkejut. Tindakan Pasca Banjir Salah satu } \\
\text { dampak bencana terhadap menurunnya kualitas hidup penduduk dapat dilihat dari } \\
\text { berbagai permasalahan kesehatan masyarakat yang terjadi. Bencana yang diikuti } \\
\text { dengan pengungsian berpotensi menimbulkan masalah kesehatan yang sebenarnya } \\
\text { diawali oleh masalah bidang/sektor lain. Kendala yang di hadapi pemerintah } \\
\text { Pemerintah Kabupaten Tebo dalam menanggulangi Bencna banjir di Kabupaten Tebo. } \\
\text { Kekurangan Dana. Dana digunakan dalam kegiatan sosialisasi yang dilakukan oleh } \\
\text { Pemerintah Kabupaten Tebo Khususnya BPBD Kabupaten Tebo. Karena dalam } \\
\text { kegiatan sosialisasi ini membutuhkan pemateri dan konsumsi untuk tamu dan } \\
\text { masyarakat. Namun pihak Pemerintah Kabupaten Tebo kekurangan dana dalam hal } \\
\text { ini. Kurang kesadaran Masyrakat. Kurangnya kesadaran disini maksudnya adalah } \\
\text { dalam kegiatan sosialisasi yang dilakukan Pihak Pemerintah Kabupaten Tebo } \\
\text { masyarakat tidak banyak yang menghadiri. }\end{array}$ \\
\hline
\end{tabular}

From the results of the author's research entitled Performance of the Regional Disaster Management Agency in Flood Disaster Management in Tebo Regency (Case Study of BPBD in Tebo Regency) as follows: Government Efforts of the Regional Disaster Management Agency in tackling Floods. Socialization Preparing for flooding This socialization was carried out for the people of the Tebo Regency Government to better know how to deal with flooding in the village. So that when the flood disaster comes the people are not surprised. Post Flood Action One of the impacts of the disaster on the declining quality of life of the population can be seen from various public health problems that occur. Disasters that are followed by displacement have the potential to cause health problems that are actually preceded by problems in other fields / sectors. Constraints faced by the government of the Tebo Regency Government in overcoming the flood disaster in Tebo Regency. Lack of funds. Funds are used in socialization activities carried out by the Government of Tebo Regency, especially $B P B D$ KAbebo District. Because in this socialization activity requires presenters and consumption for guests and the community. But the Tebo Regency Government lacked funds in this matter. Lack of community awareness. The lack of awareness here means that in the socialization activities carried out by the Tebo Regency Government, not many people attend. Though in this socialization do is for their own interests. Not many people realize that this is important.

This work is licensed under a Creative Commons Attribution-ShareAlike 4.0 International License.

\section{PENDAHULUAN}

Banjir adalah ancaman musiman yang terjadi apabila meluapnya tubuh air dari saluran yang ada dan menggenangi wilayah sekitarnya. Banjir merupakan ancaman alam yang paling sering terjadi dan paling banyak merugikan (Darmawan \& Rahman, 2017; Devitasari \& Iswahyudi, 2016; Rahmat, 2019). Sungai-sungai di Indonesia 30 tahun terakhir ini mengalami peningkatan termasuk di daerah Kabupaten Tebo. Bencana banjir termasuk bencana alam yang pasti terjadi pada setiap datangnya 
musim penghujan, seperti yang terjadi di daerah Tebo. Banjir disebabkan oleh alam atau ulah manusia sendiri. Banjir juga bisa disebabkan oleh beberapa faktor yaitu faktor hujan, faktor hancurnya retensi Daerah Aliran Sungai (DAS).

Banjir ada kalanya terjadi dengan waktu yang cepat dengan waktu genangan yang cepat pula, tetapi adakalanya banjir terjadi dengan waktu yang lama dengan waktu genangan yang lama pula. Banjir bisa terjadi karena curah hujan yang tinggi, luapan dari sungai, tersumbatnya saluran drainase atau bendungan yang runtuh. Banjir berkembang menjadi bencana jika sudah mengganggu kehidupan manusia dan bahkan mengancam keselamatannya. Penanganan bahaya banjir bisa dilakukan dengan cara struktural dan nonstruktural. Dua pengertian tentang banjir yaitu: (1) aliran sungai yang tingginya melebihi muka air normal sehingga melempas dari palung sungai yang menyebabkan adanya genangan pada lahan rendah di sisi sungai sehingga air tersebut akan mengenangi pemungkiman, (2) gelombang banjir jalan kearah hilir sistem sungai yang berinteraksi dengan kenaikan muka air di muara karena akibat badai.

Banjir di Kabupaten Tebo juga disebabkan cepatnya pertumbuhan Banjir yang terjadi di Kabupaten Tebo. Pada tahun 2017 mengakibatkan ratusan rumah di lima kelurahan yang tersebar di kecamatan Tebo Tengah terendam banjir akibat intensitas hujan yang sangat tinggi. Kondisi paling parah terjadi banjir yaitu pada tahun 2016, di mana ketinggian air yang melanda sekitar 106 hunian mencapai ketinggian 1,25 meter (BPBD Kabupaten Tebo). Bencana banjir maupun longsor kerap terjadi apa bila musim penghujan tiba. Setiap tahun di Kabupaten Tebo terjadi bencana banjir maupun longsor. Jumlah bencana banjir dan longsor seperti pada Tabel 1.

Tabel 1. Data Bencana

\begin{tabular}{clc}
\hline No. & Bencana & Tahun \\
\hline 1. & 2 Kali Banjir & 2016 \\
& 5 kali Lonsor & \\
& 1 kali Angin Putting Beliung & 2017 \\
& 1 Kali Banjir & \\
& 2 kali Lonsor & \\
& 0 kali Angin Putting Beliung &
\end{tabular}

Sumber: Kantor BPBD Kabupaten Tebo

Badan Penanggulangan Bencana Daerah sangat butuhkan dalam menyelesaikan permasalhan yang terjadi terutama sekali adalah banjir. Karena banjir memakan korban yang tidak sedikit. Badan Penanggulangan Bencana Daerah diharuskan siap dalam menghadi bencana yang setiap tahun melanda daerah Kabupaten Tebo. Bencana banjir yang setiap tahun melanda Kabupaten Tebo memakan korban yang tidak sedikit diantaranya seperti terlihat pada Tabel 2.

Tabel 2. Data Korban Bencana Banjir

\begin{tabular}{|c|c|c|c|}
\hline No. & Lokasi Bencana & Jumlah Korban/Kepala Kelaurga & Tahun \\
\hline 1. & Tebo Tengah & $70 \mathrm{KK}$ & 2016 \\
\hline 2. & Tengah Ilir & $423 \mathrm{kk}$ & \\
\hline 3. & Sumay & $155 \mathrm{kk}$ & \\
\hline 4. & Serai serumpun & $117 \mathrm{kk}$ & \\
\hline 5. & Tebo Ulu & $190 \mathrm{kk}$ & \\
\hline 6. & Tebo Ilir & $105 \mathrm{kk}$ & \\
\hline 7. & VII Koto & $311 \mathrm{kk}$ & \\
\hline 8. & VII Koto Ilir & $198 \mathrm{kk}$ & \\
\hline 9. & Muara Tabir & $2.533 \mathrm{kk}$ & \\
\hline & Total & 4. $187 \mathrm{kk}$ & \\
\hline 1. & Tebo Tengah & $1.160 \mathrm{KK}$ & 2017 \\
\hline 2. & Sumay & $358 \mathrm{kk}$ & \\
\hline 3. & Muara tbir & 1.631 & \\
\hline 4. & VII Koto Ilir & - & \\
\hline & Total & $3.211 \mathrm{kk}$ & \\
\hline
\end{tabular}

Sumber: Kantor BPBD Kabupaten Tebo. 
Dari data pada Tabel 2 dapat kita perhatikan jumlah korban setiap tahunnya. Di sini sangat diperlukan peran Badan Penggulangan Bencana dalam membantu korban bencana banjir ini dalam menyelamatkan diri korban maupun harta bendanya. Lokasi yang terkena banjir di Kabupaten Tebo ini merupakan daerah aliran sungai. Ketinggian pemukiman dengan Daerah Aliran Sungai yang rendah. Pemerintah Kabupaten Tebo terutama sekali Badan Penanggulangan Bencana Daerah sangat diperlukan untuk membantu korban.

\section{METODE}

Lokasi penelitian ini dilakukan di Instansi Badan Penanggulangan Bencana Daerah Kabupaten Tebo. Karena Daerah Kabupaten Tebo Rawan dan Sering Terjadi Banjir. Penelitian ini akan dilakukan mulai dari Maret 2018 sampai dengan april 2018. Adapun metode yang penulis gunakan dalam penelitian ini adalah metode kualitatif yang bersifat deskriptif. Menurut Sugiyono, metode penelitian kualitatif adalah metode penelitian yang digunakan untuk meneliti pada kondisi obyek alamiah, dimana peneliti adalah sebagai instrument kunci, teknik pengumpulan data dilakukan secara trianggulasi (gabungan), analisis data bersifat induktif, dan hasi penelitian kualitatif lebih menekankan makna daripada generalisasi. (Sugiyono, 2010, p. 8) Penelitian yang bersifat deskriptif bertujuan untuk pemecahan masalah pada masa sekarang, penelitian deskriptif tidak terbatas hanya sampai pada pengumpulan dan penyusunan data, tetapi meliputi analisa dan interprestasi tentang hasil data. Penelitian deskriptif membandingkan persamaan dan perbedaan fenomena tertentu lalu mengambil bentuk studi komperatif, atau mengukur suatu dimensi seperti dalam berbagai bentuk studi kuantitatif. (Surakhmad, 1980, p.139) yaitu dengan maksud untuk mengetahui serta mendapatkan gambaran tentang permasalahan yang terjadi pada tempat dan waktu tertentu, kemudian berusaha menganalisa dan menjelaskan fenomena-fenomena yang terjadi untuk pemecahan masalah mengenai fakta-fakta dan sifat-sifat dari populasi. Melalui metode kualitatif yang bersifat deskriftif, diharapkan dapat menggambarkan permasalahan dan melakukan pengkajian atau analisis.

Data yang diperoleh dari penelitian ini, terdiri atas data primer dan data sekunder. Kedua jenis data saling mendukung untuk memperkuat hasil penelitian. Adapun pengertiannya masing-masing:

Data Primer

Data primer adalah data yang diperoleh dari lokasi penelitian dan merupakan hasil observasi serta wawancara dengan bagian yang terkait dalam pengumpulan data penelitian. Data ini masih murni dan belum di olah dalam suatu proses tertentu.

Data Sekunder

Data sekunder adalah data yang diperoleh dalam bentuk yang sistematis, sudah diolah dan dipublikasikan. Data ini dapat berbentuk buku-buku,laporan-laporan dan bahan dokumen yang menyangkut masalah bencana banjir di Kab. Tebo.

Teknik pengumpulan data yang dipergunakan dalan penelitian ini yaitu:

\section{Studi Kepustakaan (Library Research)}

Yaitu suatu teknik untuk mendapatkan data yang bersifat pijakan teoritis dalam penelitian. Studi ini berguna untuk memperoleh pendapat para ahli dengan mempelajari bahan-bahan kepustakaan atau literatur berupa peraturan perundang-undangan yang isi atau materinya berkaitan dengan masalah yang akan dibahas serta buku-buku yang berhubungan dengan masalah yang akan diteliti. Studi Kepustakaan pada dasarnya merupakan langkah awal yang menentukan dalam setiap kegiatan penelitian.

\section{Studi Lapangan (Field Research)}

Yaitu dengan cara memperoleh data yang bersifat primer atau langsung didapatkan dari lokasi penelitian. Untuk mendapatkan data melalui studi lapangan maka dalam penelitian ini menggunakan 2 (dua) metode:

\section{Metode Observasi (Pengamatan)}

Yaitu studi yang disengaja dan sistematis tentang fenomena-fenomena sosial dan gejala psikis dengan jalan pengamatan serta pencatatan. Pengamatan adalah salah satu alat pengumpulan data yang 
dilakukan dengan cara mengamati dan mencatat secara sistematik gejala-gejala yang diselidiki. Pengamatan akan menjadi alat pengumpulan data yang baik, apabila: (1) Mengabdi kepada tujuan penelitian; (2) Direncanakan secara sistematik; (3) Dicatat dan dihubungkan dengan komposisikomposisi yang umum; dan (4) Dapat dicek dan dikontrol validitas, reliabilitas dan ketelitiannya.

Metode Wawancara

Wawancara adalah proses tanya jawab dalam penelitian yang berlangsung secara lisan dimana dua orang atau lebih bertatap muka dengan mendengarkan secara langsung informasi-informasi atau keterangan-keterangan yang biasanya didasarkan pada pengumpulan informasi bagi keperluan penelitian. Jenis wawancara yang dilakukan adalah wawancara bebas yang disebut juga wawancara tidak terpimpin, yaitu proses wawancara dimana interviewer tidak secara sengaja mengarahkan tanyajawab pada pokok-pokok persoalan dari fokus penelitian dan orang yang diwawancarai.

\section{Teknik Pemilihan Informan}

Purposive sampling adalah teknik pengambilan sampel sumber data dengan pertimbangan tertentu. Pertimbangan tertentu ini, minsalnya orang tersebut yang dianggap paling tahu tentang apa yang kita harapkan, atau mungkin dia sebagai pengusaha sehingga akan memudahkan peneliti menjajahi objek dan situasi sosial yang diteliti. Dengan demikian pemilihan imforman tidak berdasarkan kuantitas, tetapi kualitas dari informan terhadap masalah yang akan diteliti. Dalam pelaksanaan di lapangan guna mengumpul data, pemilihan informan dapat berkembang sesuai dengan kebutuhan dan kemantapan peneliti didalam memperoleh data. Jadi yang menjadi kepedulian bagi peneliti kualitatif adalah tuntasnya perolehan informasi dengan keragaman variasi yang ada, bukan hanya sampel sumber data (Sugiyono, 2012, p. 57). Data informan terlihat pada Tabel 3.

Tabel 3. Data Informan

\begin{tabular}{|c|c|c|c|}
\hline No. & Nama & Jabatan & Jumlah \\
\hline 1. & Drs. Hari Sugiarto & Plt. BPBD & 1 Orang \\
\hline 2. & Ir. Sadbudi Suparya & Kabid Pencegahan \&Kesiapsiagaan & 1 Orang \\
\hline 3. & Gunawan & Trc & 1 Orang \\
\hline 4. & Iwaantoni & Trc & 1 Orang \\
\hline 5. & Turiman & Korban Banjir & 1 Orang \\
\hline 6. & Azroi & Korban Banjir & 1 Orang \\
\hline \multirow[t]{2}{*}{7.} & Abdullah Majid & Korban Banjir & 1 Orang \\
\hline & & Total & 7 Orang \\
\hline
\end{tabular}

\section{Analisis Data}

Hal yang sangat penting dalam penelitian adalah menganalisis data karena hal ini dapat memberikan arti dan makna dalam suatu penelitian. Dalam penelitian ini data yang dikumpulkan melalui studi pustaka, studi lapangan yang diperoleh dari hasil observasi ditempat penelitian dengan melalui wawancara pada responden, adapun tahapan analisis data dalam penelitian ini adalah; (1) Mengumpulkan data yang berhubungan dengan penelitian; (2) Melakukan pemeriksaan data yang didapat, apakah telah sesuai dengan yang diharapkan; (3) Pengelompokkan data-data untuk menjawab pertanyaan terhadap suatu penelitian; (4) Melaksanakan Pembahasan dan perumusan tehadap data yang didapat; (5) Mengambil kesimpulan akhir terhadap data yang diteliti.

Data yang diperoleh dari penelitian akan penulis analisis dalam bentuk kualitatif, sehingga mendapatkan gambaran umum secara deskriptif atas permasalahan yang dibahas.

\section{Defenisi Konseptual Dan Operasional}

Defenisi Konseptual

Defenisi konseptual merupakan gambaran secara umum dan menyeluruh yang menyiratkan maksud dari konsep atau istilah tersebut, bersifat konstitutif, formal, dan mempunyai pengertian yang abstrak. Pada tingkat abstrak dan komplek, konsep merupakan sintesis sejumlah kesimpulan yang telah ditarik dari pengalaman dengan objek atau kejadian tertentu. (1) Banjir adalah aliran air di permukaan tanah yang relatif tinggi dan tidak dapat ditampung oleh saluran drainase atau sungai, sehingga melimpah ke kanan dan kiri serta menimbulkan genangan/aliran dalam jumlah yang melebihi 
normal dan mengakibatkan kerugian pada manusia; (2) Banjir lokal adalah banjir yang disebabkan oleh tingginya curah hujan dalam periode waktu tertentu (intensitas hujan) yang dapat menggenangi daerah yang relatif lebih rendah (ledokan); (3) Persepsi adalah proses pencarian informasi untuk dipahami; (5) Partisipasi adalah kontribusi sukarela dari masyarakat terhadap proyek tanpa ikut serta dalam pengambilan keputusan

Defenisi Operasional

Defenisi operasional tak lain dari pada mengubah konsep-konsep yang berupa konstruk dengan kata-kata yang menggambarkan perilaku atau gejala yang dapat diamati, dan dapat diuji dan ditentukan kebenarannya oleh orang lain. (1) Dengan Melihat peran Badan Penanggulangan banjir Daerah (BPBD) dalam menanggulangi resiko banjir yang terjadi di Kab. Tebo; (2) Dengan melihat hubungan kerja sama antara pemerintah daerah dan masyarakata dalam menanggulangi bencana banjir.

\section{HASIL DAN PEMBAHASAN}

\section{Upaya Pemerintah Badan Penanggulan Bencana Daerah dalam menanggulangi Bencana Banjir}

Dalam kamus Bahasa Indonesia menyebutkan pengertian upaya adalah tindakan yang dilakukan seseorang, untuk mencapai apa yang diinginkan atau merupakan sebuah strategi. Upaya adalah aspek yang dinamis dalam kedudukan (status) terhadap sesuatu. Apabila seseorang melakukan hak dan kewajibannya sesuai dengan kedudukannya, maka ia menjalankan suatu upaya (Muhaiyat, 2018; Suharto 2002; Soekamto 1984, p. 237). Upaya dijelaskan sebagai usaha (syarat) suatu cara, juga dapat dimaksud sebagai suatu kegiatan yang dilakukan secara sistematis, terencana dan terarah untuk menjaga sesuatu hal agar tidak meluas atau timbul. Upaya yang dialkukan Badan Penaggulangan Bencana Daerah Kabupaten Tebo dalam menaggulangi Bencana Banjir diantaranya:

\section{Sosialisasi Pesiapan menghadapi banjir}

Sosialisasi ini dilakukan untuk masyarakat Pemerintah Kabupaten Tebo supaya lebih tahu bagaimana persiapan mengahadapi banjir di kelurahan tesebut. Supaya disaat bencana banjir datang masyarakat tidak terkejut. Sebagaimana wawancara penulis dengan Kepla Badan Penanggulangan Bencana Daerah Kabupaten Tebo, apa tujuan dari sosialisasi yang dilakukan oleh pemerintah Pemerintah Kabupaten Tebo tentang bencana banjir ini;

"Yang mana Sosialisasi ini bertujuan untuk member persiapan terhadap masyarakat tentang apa yang dialkukan sewaktu banjir datang. Terkadang banjir datang secara mendadak. Hujan hanya gerimis bisa juga menjadi banjir. Karena banjir bisa saja datang dari hulunya". ${ }^{1}$

Dari wawancara penulis dengan Badan Penaggulangan Bencana Daerah Kabupaten Tebo ini dapat kita beri kesimpulan yang mana sosialisasi ini dilakukan untuk supaya masyarakat lebih tau tentang bagaimana menghadapi banjir nantinya. Dan masyarakat sudah tau apa yang dilakukan jika banjir nantinya. Pada saat penulis wawancara dengan tim Badan Penanggulangan Bencana Daerah (BPBD) Kabupaten Tebo. Sosialisi seperti apa yang dilakukan di Pemerintah Kabupaten Tebo tentang banjir ini;

"sosialisasi yang kami lakukan ini banyak sekali diantaranya persiapan menghadapi banjir, simulasi menggunakan alat pengamanan, pelampung, pembuatan tenda dan lain sebagainya.". ${ }^{2}$

Dari wawancara penulis dengan pihak Badan Penanggulangan Bencana Daerah Kabupaten Tebo mengatakan sosialisasi dilakukan bertujuan supaya masyarakat lebih tau tentang cara menhadapi di saat dilanda bencana banjir nantinya. Poin-poin yang di sosialisasikan tentang cara menhadapai banjir diantarantaranya adalah sebagai berikut: (1) Kenali wilayah tempat tinggal, sebab banjir biasanya terjadi di daerah yang sebelumnya sudah mengalami bencana tersebut; (2) Buat Perencanaan dan tindakan antisipasi, seperti langkah-langkah evakuasi dan menetapkan lokasi yang aman untuk mengungsi; (3) Dengarkan radio untuk memantau perkembangan informasi dan beritahu kepada para

\footnotetext{
${ }^{1}$ Wawancara penulis. pada tanggal 3 Agustus 2018, jam 09.23 wib

${ }^{2}$ Wawancara penulis dengan pada tanggal 4 Agustus 2018, jam 10.00 wib
} 
tetangga; (4) Pindahkan sampah dan bahan-bahan kimia berbahaya agar tidak terbawa arus banjir; (5) Pindahkan Furniture dan tempat tidur ke tempat yang dianggap aman; (6) Tempatkan karung pasir di atas lubang toilet agar kotoran tidak naik ke permukaan; (7) Matikan listrik dan sumber gas; (8) Laporkan kepada petugas keamanan, RT, RW atau Pos Polisi terdekat, jika rumah anda akan ditinggalkan atau mengungsi.

Berdasarkan poin-poin yang disampaiakn oleh pihak Badan Penanggulangan Bencana Daerah Kabupaten Tebo ini sangat penting sekali. Di mana Pemerintah Kabupaten Tebo setiap tahunnya pasti terkena bencana banir. Banjir yang melanda masyrakat mengalami berbagai kerugian. Berdasarkan wawancara penulis dengan masyarakat. Penulis menanyakan bagaimana dampak dari banjir yang terjadi;

"bencana banjir yang setiap tahunnya melanda kami ini. Kami mengalami banyak sekali kerugian, mulai dari harta, rumah maupun kami sendiri. Yang mana harta banyak yang hilang. Rumah jelas rusak dan lain sebagainya. Dari banjir ini kami banyak sekali kerugian". ${ }^{3}$

Dari wawancara penulis tersebut kita tahu bahwa bencana banjir yang melanda masyarakat Kabupaten Tebo ini mengalami banyak kerugian seperti harta benda dan mereka sendiri. Mereka harus meninggalkan rumah berminggu-minggu disaaat dilanda banjir.

Telah kita dengar dan saksikan berbagai bencana alam telah terjadi hampir di seluruh dunia, di Negara kita Indonesia pun tidak luput dari berbagai bencana alam, salah satunya banjir. Bencana alam itu selalu ada menghiasi warna-warni kehidupan di alam ini. Baik itu merupakan bencana alam kecil atau pun besar. Bencana alam banyak yang menimbulkan kerusakan dalam skala kecil maupun yang dapat menimbulkan kerusakan dalam skala besar. Nah sekarang bagaimana kita cara menanggulanginya. Agar banjir/bencana tidak menimbulkan berbagai dampak negatif, jadi kita perlu melakukan suatu upaya untuk mengurangi risiko bencana, baik melalui pembangunan fisik maupun penyadaran dan peningkatan kemampuan dalam menghadapi ancaman bencana atau yang sering kita sebut dengan mitigasi bencana.

Pemerintah Pemerintah Kabupaten Tebo yakni BPBD mensosialisasikan kepada masyarakat apa yang perlu dilakukan selama terjadi banjir. Masyarakat memerlukan pengetahuan tentang tindakan yang dilakukan selama terjadi banjir. Mengingat masyrakat terkadang menghadapi banjir ada yang prustasi atau stress dengan terjadinya banjir dan kehilangan harta benda dan ada juga yang biasa saja. Pemerintah Kabupaten Tebo juga bekerja sama dengan tokoh masyrakat dan BPBD Kabupaten Tebo yang lebih menguasai tentang tata cara menghadapi disaat terkena banjir. Dari wawancara penulis dengan pihak BPBD Kabupaten Tebo mengatakan tentang apa yang dilakukan di saat terkena banjir sebagai berikut: (1) Menyelamatkan diri ke tempat yang aman; (2) Siapkan radio, senter, baterai, lilin dan pemantik api yang tahan air; (3) Siapkan bahan makanan yang tahan air (dalam kemasan plastik atau kaleng), sepatu karet dan sarung tangan; (4) Siapkan obat-obatan untuk pertolongan pertama; (5) Tas anti air dan catatan penting berisi alamat untuk menghubungi otoritas yang berwenang (satkorlak).

Dari beberapa uraian tersebut sangat perlu diperhatikan oleh masyarakat yang terkena musibah banjir salah satunya poin pertama ini menyangkut nyawa. Jadi yang perlu dilakukan disaat terkena banjir pertama sekali ada amankan diri dan keluarga baru yang lainnya. Sebagai mana wawancara penulis dengan Tokoh Masyarakat Kabupaten Tebo:

"kami jikalau tekena banjir ya menyelamatkan diri dulu baru kami memikirkan yang lainnya. Nyawa hanya satu kalau masalah harta bisa dicari."

Dari wawancara penulis ini dapat kita analisa masyarakat sudah berpikir cerdas jika terkena banjir yang dilakukan adalah menyelamatkan diri. Namun ada juga masyrakat yang tidak tau apa yang dilakukan dikarenakan mereka stress menghadapi musibah tersebut. Ini sangat di penting sosialisasi bagai mana menghadapi banjir yang melanda. Pihak pemerintah Kabupaten Tebo menuturkan:

"sosialisasi kami lakukan bertujuan supaya masyrakat tidak bingung menhadapi banjir. Yang sebelumnya tidak tahu yang dilakukan dengan adanya sosialisasi ini hendak nya masyarakat mengenal dan tau apa saja yang dilakukan dan bagai mana caranya. Dari sosialisasi yan kami

\footnotetext{
${ }^{3}$ Wawancara penulis dengan tokoh masyrakat Bapak Ardianto pada tanggal 6 Agustus 2018 jam 11.12 wib

${ }^{4}$ Wawancara penlis dengan Bapak Mugino Ketua RT pada tanggal 2 agustus 2018 jam 13.09 wib
} 
lakukan ini sangat penting sekali bagi masyrakat bukan hanya masyarakat jaya setia saja namun masyrakat lain yang terkena musibah banjir juga perlu tahu tentang ini". 5

Wawancara penulis tersebut ini membuktikan betapa pentingnya sosialisasi tentang apa yang dilakukan disaat dilanda banjir ini. Sebagian masyrakat tau tentang hal apa yang dilakukan disaat dilanda banjir adalah dari sosialisasi dari pihak Pemerintah Kabupaten Tebo bekerja sama dengan BPBD Kabupaten Tebo sebagai mana wawancara penulis dengan tokoh masyrakat:

"tentang apa yang dilakukan di saat terkena musibah banjir ini kami tahunya dari pihak kelurahan. Mereka pernah buat acara di Aula dengan mengundang tim BPBD Kabupaten Tebo. Mereka memberitahu kami tentang apa yang dilakukan disaat terkena banjir. Acara ini kadang di masjid kadang di kantor Camat Maupun di Kantor Desa". 6

Dari wawancara penulis tersebut tempat acara sosialisasi dilakukan di Kantor Camat maupun di Kantor Desa. Dengan mengundang pemateri dari Badan Penanggulangan Bencanan Daerah Kabupaten Tebo.

\section{Tindakan Pasca Banjir}

Salah satu dampak bencana terhadap menurunnya kualitas hidup penduduk dapat dilihat dari berbagai permasalahan kesehatan masyarakat yang terjadi. Bencana yang diikuti dengan pengungsian berpotensi menimbulkan masalah kesehatan yang sebenarnya diawali oleh masalah bidang/sektor lain. Bencana gempa bumi, banjir, longsor dan letusan gunung berapi, dalam jangka pendek dapat berdampak pada korban meninggal, korban cedera berat yang memerlukan perawatan intensif, peningkatan risiko penyakit menular, kerusakan fasilitas kesehatan dan sistem penyediaan air ${ }^{7}$

Timbulnya masalah kesehatan antara lain berawal dari kurangnya air bersih yang berakibat pada buruknya kebersihan diri, buruknya sanitasi lingkungan yang merupakan awal dari perkembangbiakan beberapa jenis penyakit menular.

Persediaan pangan yang tidak mencukupi juga merupakan awal dari proses terjadinya penurunan derajat kesehatan yang dalam jangka panjang akan mempengaruhi secara langsung tingkat pemenuhan kebutuhan gizi korban bencana. Pengungsian tempat tinggal (shelter) yang ada sering tidak memenuhi syarat kesehatan sehingga secara langsung maupun tidak langsung dapat menurunkan daya tahan tubuh dan bila tidak segera ditanggulangi akan menimbulkan masalah di bidang kesehatan. Sementara itu, pemberian pelayanan kesehatan pada kondisi bencana sering menemui banyak kendala akibat rusaknya fasilitas kesehatan, tidak memadainya jumlah dan jenis obat serta alat kesehatan, terbatasnya tenaga kesehatan dan dana operasional. Kondisi ini tentunya dapat menimbulkan dampak lebih buruk bila tidak segera ditangani. ${ }^{8}$

Dampak bencana terhadap kesehatan masyarakat relatif berbeda-beda, antara lain tergantung dari jenis dan besaran bencana yang terjadi. Kasus cedera yang memerlukan perawatan medis, misalnya, relatif lebih banyak dijumpai pada bencana gempa bumi dibandingkan dengan kasus cedera akibat banjir dan gelombang pasang. Sebaliknya, bencana banjir yang terjadi dalam waktu relatif lama dapat menyebabkan kerusakan sistem sanitasi dan air bersih, serta menimbulkan potensi kejadian luar biasa (KLB) penyakit-penyakit yang ditularkan melalui media air (water-borne diseases) seperti diare dan leptospirosis. Terkait dengan bencana gempa bumi, selain dipengaruhi kekuatan gempa, ada tiga faktor yang dapat mempengaruhi banyak sedikitnya korban meninggal dan cedera akibat bencana ini, yakni: tipe rumah, waktu pada hari terjadinya gempa dan kepadatan penduduk. ${ }^{9}$

Tindakan yang dilakukan setelah banjir ini dilakukan oleh pemerintaha Pemerintah Kabupaten Tebo dengan pihak Rumah Sakit Tebo. Karena ini menyangkut kesehatan masyarakat. Yang sakit ataupun yang defresi akibat bencana banjir yang melanda masyarakat Tebo. Materi yang disampaikan oleh pihak Dinas Kesehatan Kabupaten Tebo diantaranya: (1) Pastikan peralatan kebutuhan emergency tetap kering. Jangan makan dengan menggunakan peralatan yang terkontaminasi dengan

\footnotetext{
${ }^{5}$ Wawancara penulis dengan Pada tanggal 6 Agustus 2018 jam 09.45 wib

${ }^{6}$ Wawancara penulis dengan Tokoh Masyrakat pada tanggal 6 agustus 2018 jam 15.23 wib

7 (Pan American Health Organization, 2006).

8 (Pusat Penanggulangan Masalah Kesehatan Sekretariat Jenderal Departemen Kesehatan, 2001).

${ }^{9}$ (Pan American Health Organization, 2006).
} 
air banjir. Sterilkan peralatan makanan dengan menggunakan air panas; (2) Jangan menggunakan perlatan listrik yang terendam banjir; (3) Hati-hati dengan ular, kalajengking atau binatang berbisa lainnya yang masuk ke dalam rumah; (4) Masuk ke dalam rumah dengan menggunakan sepatu karet/boot dan sarung tangan; (5) Bersihkan sisa lumpur yang berada di lantai atau menempel di dinding sesegera mungkin. Sisa lumpur yang kering akan menimbulkan debu dan dapat mengganggu kesehatan (menggangu saluran pernapasan, iritasi mata dan gatal-gatal); (6) Dengarkan radio untuk mendengarkan informasi tentang tips menghadapi bahaya banjir.

Materi lain juga disampaikan oleh Pihak Dinas Kesehatan sebagai mana wawancara penulis. Materi apa saja yang disampaikan saat bapak sosialisasi di Pemerintah Kabupaten Tebo tentang Banjir:

"Banjir menimbulkan dampak buruk terhadap kesehatan masyarakat. Hal ini disebabkan oleh kondisi pasca banjir yang rawan menjadi faktor pemicu munculnya penyakit. Berbagai kondisi tersebut adalah (1) Berkembangnya vektor penyakit berupa hewan seperti tikus dan nyamuk; (2) Makanan seperti persediaan beras dan sayur mayur terkontaminasi; (3) Sumber air tercemar; (4) sampah berserakan; (5) Fasilitas kakus kurang; (6) Persediaan air bersih minim; dan (7) Fasilitas pengungsian buruk dan tidak sehat". ${ }^{10}$

Dari hasil wawancara penulis dapat kita analisa yang mana pihak DInas Kesehatan Kabupaten Tebo memeberi penyuluhan tentang pentingnya kesehata diperhatikan setelah banjir. Kesehatan merupakan salah satu faktor penting untuk melakukan aktivitas sehari-hari. Oleh sebab itu kita tidak boleh meremehkan kesehatan badan kita. Banyak orang memiliki berbagai keluhan kesehatan akibat tidak memperdulikan kesehatan tubuhnya setelah banjir baik itu keluhan yang ringan hingga keluhan yang berat seperti: pencernaan, Batuk, Deman dan sebagainya.

Banyak hal yang dapat dilakukan untuk menjaga kesehatan setelah banjir diantaranya adalah: mengkonsumsi makanan bergizi, mengkonsumsi makan yang sehat dan bersih, istirahat yang cukup, mebersihkan perabot dan pekarangan rumah supaya terhindar dari nyamuk.

\section{Kendala yang di hadapi pemerintah Pemerintah Kabupaten Tebo dalam menanggulangi Bencna banjir di Kabupaten Tebo}

Dalam penelitian yang penulis lakukan ini, penulis menemukan berbagai kendala yang di hadapai oleh pihak Pemerintah Pemerintah Kabupaten Tebo. Sebagai mana wawancara penulis dengan BPBD Kabupaten Tebo;

“jaya setia ini sering terjadi banjir boleh dikatakan setiap tahun terjadi banjir disini. Dari seringnya terjadi banjir kami sering melakukan sosialisasi dengan masyrakat mengajak masyrakat mengadakan pertemuan baik dengan kami, pihak Badan Penanggulangan Bencana daerah, pihak Dinas Kesehatan yang menyangkut kesehatan masyarakat. Dalam sosialisasi ini kami juga banyak mengalami kendala seperti dana, kurangnya perhatian dari masyrakat dan lain sebagainya". ${ }^{11}$

Dari wawancara penulis dengan Lurah Jaya Setia dalam mengadakan acara sosialisasi tentang Bencana Banjir mengalami kendala diantaranya:

\section{Kekurangan Dana}

Dana digunakan dalam kegiatan sosialisasi yang dilakukan oleh Pemerintah Kabupaten Tebo Khususnya BPBD KAbupaten Tebo. Karena dalam kegiatan sosialisasi ini membutuhkan pemateri dan konsumsi untuk tamu dan masyarakat. Namun pihak Pemerintah Kabupaten Tebo kekurangan dana dalam hal ini. Sosialisasi yang dilakukan tidak maskismal sebagai mana wawancara penulis dengan pihak Pemerintah Kabupaten Tebo. Penulis menanyakan dalam kegiatan sosialisasi ini dananya bersumber dari mana;

\footnotetext{
${ }^{10}$ Wawancara penulis dengan Bapak Haidir, S.KM pada tanggal 6 Agustus 2018 Jam 11.20 wib)

${ }^{11}$ Wawancara penulis dengan BPBD pada tanggal 9 Agustus 2018 jam 11.20 wib.
} 
"kegiatan yang kami lakukan untuk masayrakat KAbupaten Tebo. Kami merasa tidak mempunya dana, terkadang dana dalam kegiatan yang kami lakukan ini sumbernya dari pendaatan daerah yang di khusukan untuk Bencana, kadang dana tersebut tidak cukup untuk hal tersebut". ${ }^{12}$

Dari wawancara penulis tersebut dana yang digunakan saat sosialisasi dengan masyarakat adalah bersumber dari masyrakat itu sendiri. Inilah yang menjadaai kendala pihak pemerintah Kabupaten Tebo.

\section{Kurang kesadaran Masyrakat}

Kurangnya kesadaran disini maksudnya adalah dalam kegiatan sosialisasi yang dilakukan Pihak Pemerintah Kabupaten Tebo masyarakat tidak banyak yang menghadiri. Padahal dalam sosialisasi ini lakukan adalah untuk kepentingan mereka sendiri. Masyrakat tidak banyak yang menyadari bahwa hal tersebut penting. Materi yang disampaikan saat materi adala apa yang mereka lakukan saat banjir mapun setelah banjir. Sebagai mana wawancara penulis dengan Pihak BPBD;

"sosialisasi yang kami lakukan ini masyrakat banyak yang tidak mau menghadirinya. Dengan alas an adalah mereka lagi kerja dan lain sebgainya. Pada yang kami sampaikan saat banjir dan tentang apa yang dilakukan sebelum banjir nmauun sesudah banjir". ${ }^{13}$

Dari wawancara penulis dengan pihak Pemerintah Kabupaten Tebo, masyrakat yang tidak mengikuti acacara sosialisasi yang dilakukan pihak Pemerintah Kabupaten Tebo mereka sibuk dengan kerja.

\section{SIMPULAN}

Upaya Pemerintah Badan Penanggulan Bencana Daerah dalam menanggulangi Bencana Banjir, yaitu: Pertama, Sosialisasi Pesiapan menghadapi banjir Sosialisasi ini dilakukan untuk masyarakat Pemerintah Kabupaten Tebo supaya lebih tahu bagaimana persiapan mengahadapi banjir di kelurahan tesebut. Supaya disaat bencana banjir datang masyarakat tidak terkejut. Kedua, Tindakan Pasca Banjir Salah satu dampak bencana terhadap menurunnya kualitas hidup penduduk dapat dilihat dari berbagai permasalahan kesehatan masyarakat yang terjadi. Bencana yang diikuti dengan pengungsian berpotensi menimbulkan masalah kesehatan yang sebenarnya diawali oleh masalah bidang/sektor lain.

Kendala yang di hadapi pemerintah Pemerintah Kabupaten Tebo dalam menanggulangi Bencna banjir di Kabupaten Tebo, yaitu: Pertama, Kekurangan Dana. Dana digunakan dalam kegiatan sosialisasi yang dilakukan oleh Pemerintah Kabupaten Tebo Khususnya BPBD KAbupaten Tebo. Karena dalam kegiatan sosialisasi ini membutuhkan pemateri dan konsumsi untuk tamu dan masyarakat. Namun pihak Pemerintah Kabupaten Tebo kekurangan dana dalam hal ini. Kedua, Kurang kesadaran Masyrakat. Kurangnya kesadaran disini maksudnya adalah dalam kegiatan sosialisasi yang dilakukan Pihak Pemerintah Kabupaten Tebo masyarakat tidak banyak yang menghadiri. Padahal dalam sosialisasi ini lakukan adalah untuk kepentingan mereka sendiri. Masyrakat tidak banyak yang menyadari bahwa hal tersebut penting

Dari kesimpulan tersebut, maka penulis memberikan beberapa saran yang menurut penulis perlu di perbaiki. Adapun saran-saran penulis sebagai berikut kepada pemerintah Kabupaten Tebo untuk memperhatikan masyarakat yang terkena dampak bencana di perhatikan dengan serius. Dan diharapkan kepada tim BPBD selalu berkoordiansi dengan pihak terkait lainnya dalam menangani benca.

\section{DAFTAR PUSTAKA}

Darmawan, A. K., \& Rahman, T. (2017, November). Sistem peringatan dini banjir menggunakan arduino dan sms gateway untuk daerah Pamekasan. In Prosiding SEHATI (Seminar Nasional Humaniora dan Aplikasi Teknologi Informasi) (Vol. 3, No. 1, pp. 9-12).

\footnotetext{
${ }^{12}$ Wawancara penulis dengan Bapak Yandri, S.Sos pada tanggal 8 Agustus 2018, jam 10.45 wib

${ }^{13}$ Wawancara penulis dengan Bapak Yandri, S.Sos pada tanggal 8 Agustus 2018, jam 12.45 wib
} 
Jurnal Politik dan Pemerintah Daerah, 1 (2), 2019 - 94

Ahmad Udori, Miranti Miranti

Devitasari, I., \& Iswahyudi, A. (2016, November). Sistem informasi geografis untuk pemetaan potensi umkm sektor industri, perdagangan dan jasa menggunakan platform mobile android. In Prosiding SEHATI (Seminar Nasional Humaniora dan Aplikasi Teknologi Informasi) (Vol. 2, No. 1, pp. 109-113).

Muhaiyat, B. (2018). Upaya pembinaan dan pelatihan gelandangan dan pengemis oleh dinas sosial dan pemakaman Kota Pekanbaru (Studi kasus di Kota Pekanbaru) (Doctoral dissertation, Universitas Islam Negeri Sultan Syarif Kasim Riau).

Rahmat, S. I. (2019). Sistem peringatan dini banjir menggunakan sensor ultrasonik berbasis Arduino Uno. Jurnal Manajemen dan Teknik Informatika (JUMANTAKA), 3(1).

Soekamto, C. I. (1984). Batik dan membatik: suatu perkenalan seni batik Indonesia kepada anakanak. Akadoma.

Sugiyono, S. (2010). Metodologi penelitian administrasi, Alfabeta: Bandung.

Sugiyono, S. (2012). Metode penelitian kuantitatif kualitatif dan R\&D.Alfabeta : Bandung

Suharto, E. (2005). Membangun masyarakat memberdayakan rakyat. Bandung: PT refika aditama.

Surakhmad, W. (1980). Interaksi belajar mengajar. Bandung: Jemmars. 